\title{
Pengaruh Ekstrak Bawang Merah (Allium ascalonicum L) terhadap Kadar Asam Lemak Bebas Pada Penggunaan Berulang Minyak Goreng Kelapa Sawit
}

\author{
Effect of Shallot Extract (Allium ascalonicum L) Toward Free Fatty Acid Levels in Repeated Use of \\ Palm Cooking Oil
}

\author{
Resa Widiamawarta ${ }^{1}$, Nur Hidayati ${ }^{2} *$ Mardiyono $^{3}$ \\ ${ }^{1,2}$ Fakultas Ilmu Kesehatan Universitas Setia Budi \\ ${ }^{3}$ Fakultas Farmasi Universitas Setia Budi Surakarta \\ *Corresponding author: nurhidayati.nn@gmail.com
}

\section{ABSTRAK}

Minyak merupakan salah satu sumber energi penting dalam tubuh manusia. Minyak memberikan energi kedalam tubuh manusia 9 kalori tiap gram lemak. Asam lemak bebas atau Free Fatty Acid (FFA) merupakan hasil hidrolisis trigliserida yang mudah teroksidasi sehingga menyebabkan ketengikan (rancidity) pada minyak. Berbagai macam reaksi yang terjadi selama proses penggorengan seperti reaksi oksidasi, hidrolisis, polimerisasi, dan reaksi dengan logam dapat mengakibatkan minyak menjadi rusak. Penelitian ini bertujuan untuk mengetahui pengaruh nyata penambahan ekstrak bawang merah terhadap minyak goreng kelapa sawit yang digunakan penggorengan berulang-ulang dengan materi tergoreng tempe.

Minyak goreng kelapa sawit sebelum digunakan untuk penggorengan ditetapkan sebagai kontrol tanpa penyimpanan 24 jam dan penyimpanan 24 jam. Minyak goreng kelapa sawit digunakan untuk menggoreng tempe dengan pengulangan penggorengan pertama, kedua, dan ketiga. Perlakuan yang diberikan dengan penambahan ekstrak bawang merah dan tanpa ekstrak bawang merah dan ditetapkan kadar asam lemak bebasnya. Metode yang digunakan untuk penetapan kadar asam lemak bebas adalah Alkalimetri. Analisis data dilakukan dengan menggunakan uji statistik Anova satu jalan.

Hasil penelitian menunjukkan bahwa kadar asam lemak bebas pada minyak goreng pada kontrol tanpa penyimpanan 24 jam dan penyimpanan 24 jam adalah 0,13\%. Kadar asam lemak bebas pada minyak goreng setelah dilakukan penggorengan pertama, kedua, ketiga, tanpa pemberian ekstrak bawang merah adalah 0,44\%, 0,60\%, 0,74\%, sedangkan minyak goreng dengan pemberian ekstrak bawang merah adalah 0,28\%, 0,44\%, 0,57\%. Uji statistik menunjukkan adanya pengaruh nyata terhadap peningkatan kadar asam lemak bebas dengan pemberian ekstrak bawang merah.

Kata kunci: asam lemak bebas, ekstrak bawang merah, minyak goreng kelapa sawit

\section{ABSTRACT}

Oil is one important source of energy in the human body. Oil gives 9 calories energy per gram of fat to the human body. Free Fatty Acid (FFA) is the result of a triglyceride hydrolysis easily oxidized, causing rancidity on oil. Various reactions that occur during the frying process such as oxidation, hydrolysis, polymerization, and the reaction with metal may result in oil being damaged. This research aims to determine the real effect of the addition of shallot extract against palm oil which is used repeatedly with a fried material is soybean cake.

Before palm cooking oil is used for frying, it is set as a control with 24 hours of storage and without. Palm cooking oil used for frying soybean with the repetition of a frying pan first, second, and third. The treatment given by the addition of shallot extracts and without later established the levels of free fatty acids. The method used for the determination of free fatty acid is Alcalimetry. Data analysis was performed using one way Anova statistical test.

The results showed that free fatty acids levels in cooking oil on storage control with 24 hours storage and with was $0.13 \%$. Free fatty acids levels in cooking oil after frying is done first, second, third, without the shallot extract was $0.44 \%, 0.60 \%, 0.74 \%$, while the cooking oil with shallot extract was $0.28 \%, 0.44 \%, 0.57 \%$. The statistical test showed a significant effect on the increase in free fatty acid levels by increasing of shallot extracts.

Keywords: free fatty acid, shallot extract, palm cooking oil

\section{PENDAHULUAN}

Kebutuhan dunia terhadap minyak dan lemak nabati terus mengalami peningkatan setiap tahun. Pada tahun 2006 produksi minyak dan lemak na- 
bati mencapai 123 juta ton dan diprediksi terus meningkat setiap tahun. Sebanyak 45,5 juta ton minyak dan lemak tersebut berasal dari minyak kelapa sawit (Ayustaningwarno, 2012).

Minyak goreng dapat diproduksi dari berbagai macam bahan mentah, misal nya kelapa, kopra, kelapa sawit, kacang kedelai, biji jagung (lembaganya), biji bunga matahari, biji zaitun (olive), dan lain-lain. Banyaknya permintaan akan bahan pangan digoreng merupakan suatu bukti yang nyata mengenai betapa besarnya jumlah bahan pangan digoreng yang dikonsumsi manusia oleh lapisan masyarakat dari segala tingkat usia (Ketaren, 2012).

Reaksi oksidasi pada minyak dapat dihambat dengan penambahan zat antioksidan. Zat antioksidan ada dua macam yaitu antioksidan alami dan sintetik. Pada umumnya zat antioksidan yang digunakan oleh masyarakat adalah jenis antioksidan sintetik. Antioksi dan tersebut diantarannya Butylated Hydroxy Anisol (BHA), Butylated Hydroxy Toluen (BHT), Tert-butyl Hydroquinone (TBHQ), dan Propilgallate. (Ayucitra, et al., 2011; Brewer, M.S. 2011). Menurut Panagan (2010) bahan antioksidan tersebut dapat meracuni minyak dan menimbulkan efek jangka panjang yaitu bersifat karsinogenik atau dapat menimbulkan kanker.

Antioksidan alami memiliki beberapa keunggulan dibandingkan dengan antioksidan sintetik karena antioksidan alami bersifat aman bila dikonsumsi dan dapat menghambat reaksi kimia oksidasi yang merusak makromolekul. Antioksidan alami yang sering ditemukan dan dimanfaatkan dalam makanan antara lain bawang merah, bawang putih, apel, buah berry, sayuran hijau, brokoli, rosemary, dan sage. Bahan-bahan makanan tersebut memiliki kandungan flavonol dalam konsentrasi yang tinggi yang dapat memperlambat laju oksidasi pada minyak goreng kelapa sawit. Sehinga dapat menghambat peningkatan kadar asam lemak bebas (Ayucitra et al., 2011).

Bawang merah merupakan bahan alami yang memiliki kandungan zat-zat aktif yang sangat ba- gi tubuh. Bawang merah mengandung senyawa flavonoid yang dapat berfungsi sebagai antioksidan alami yang dapat menekan efek karsinogenik dari senyawa radikal bebas. Kandungan senyawa dalam bawang merah juga dapat juga dapat berperan dalam menetralkan zat-zat toksin berbahaya dan membuangnya dari dalam tubuh (Karneli et al., 2015). Menurut Panagan (2010) ekstrak bawang merah dapat menurunkan kadar asam lemak bebas sebagai indikasi tingkat kerusakan minyak.

Tujuan dari penelitian ini adalah untuk mengetahui kadar asam lemak bebas pada minyak goreng kelapa sawit yang dilakukan penggorengan berulang-ulang dengan dan tanpa penambahan ekstrak bawang merah pada materi tergoreng tempe dan mengetahui pengaruh nyata penambahan ekstrak bawang merah terhadap minyak goreng kelapa sawit yang digunakan penggorengan berulang-ulang dengan materi tergoreng tempe.

\section{METODE PENELITIAN}

\section{Proses Ekstraksi}

Proses Ekstraksi dilakukan dengan cara maserasi suhu ruangan. Serbuk bawang merah yang diperoleh setelah pengeringan dilakukan perendaman dengan cara diambil 400 gram bahan kemudian direndam dengan pelarut etanol $96 \%$ sebanyak 3000 mlselama 5X24 jam sambil sesekali dikocok. Maserat yang dihasilkan kemudian dipekatkan dengan cara menguapkan pelarutnya dengan vaccum rotatory evaporator dengan tekanan rendah pada suhu $70^{\circ} \mathrm{C}$ (Senja et al., 2014; Ayustaningwarno, Fitriyono. 2012).

\section{Prosedur Persiapan Sampel}

Prosedur persiapan sampel dilakukan berdasarkan variasi pengulangan penggorengan dan penambahan ekstrak atau tanpa ekstrak. Variasi pertama adalah minyak goreng yang belum dilakukan penggorengan tanpa disimpan 24 jam dilakukan penetapan kadar asam lemak bebas (kontrol). Variasi kedua adalah minyak goreng yang belum digunakan untuk proses penggorengan disimpan selama 24 jam (kontrol 24 jam). Variasi 
ketiga adalah minyak goreng yang tidak diberi penambahan ekstrak bawang merah dilakukan penggorengan pertama, kedua, ketiga lalu disimpan 24 jam kemudian ditentukan kadar asam lemak bebasnya. Variasi keempat adalah minyak goreng yang sebelum digunakan untuk penggorengan ditambahkan ekstrak bawang merah lalu disimpan 24 jam dan kemudian ditentukan kadar asam lemak bebasnya (Gunawan et al., 2003; Ketaren, 2012). Pada penetapan kadar asam lemak bebas dilakukan pengulangan tiga kali pada setiap proses penggorengan.

\section{HASIL PENELITIAN DAN PEMBAHASAN}

a. Data Hasil Penetapan Kadar Asam Lemak Bebas

Berdasarkan hasil penelitian, rerata kadar asam lemak bebas pada minyak goreng kelapa sawit dengan perlakuan kontrol tanpa penyimpanan 24 jam, dengan penyimpanan 24 jam, pemberian ekstrak bawang merah, dan tanpa pemberian ekstrak bawang merah disajikan dalam Tabel 1, 2, dan 3 .

b. Grafik Rerata Kadar Asam Lemak Bebas Grafik rerata kadar Asam Lemak Bebas disajikan, pada Gambar 1.

\section{c. Prosentase Penurunan Kadar Asam Lemak}

\section{Bebas}

Data prosentase penurunan kadar asam lemak bebas disajikan pada Tabel 2 .

\section{d. Grafik Prosentase Penurunan Kadar Asam}

\section{Lemak Bebas}

Grafik prosentase penurunan kadar Asam Lemak Bebas ditampilkan pada Gambar 2.

Tabel 1. Data Rerata Kadar Asam Lemak Bebas

\begin{tabular}{|c|c|c|}
\hline No & Perlakuan & $\begin{array}{c}\text { Kadar Rata-rata Asam Lemak } \\
\text { Bebas }\end{array}$ \\
\hline 1. & Kontrol tanpa disimpan 24 jam & $0,13 \%$ \\
\hline 2. & Kontrol dengan disimpan 24 jam & $0,13 \%$ \\
\hline 3. & P1 Tanpa Ekstrak & $0,44 \%$ \\
\hline 4. & P2 Tanpa Ekstrak & $0,60 \%$ \\
\hline 5. & P3 Tanpa Ekstrak & $0,74 \%$ \\
\hline 6. & P1 Dengan Ekstrak & $0,28 \%$ \\
\hline 7. & P2 Dengan Ekstrak & $0,44 \%$ \\
\hline 8. & P3 Dengan Ekstrak & $0,57 \%$ \\
\hline
\end{tabular}

Keterangan :

P1 : Sampel minyak goreng kelapa sawit setelah dilakukan penggorengan pertama P2 : Sampel minyak goreng kelapa sawit setelah dilakukan penggorengan kedua

P3 : Sampel minyak goreng kelapa sawit setelah dilakukan penggorengan ketiga

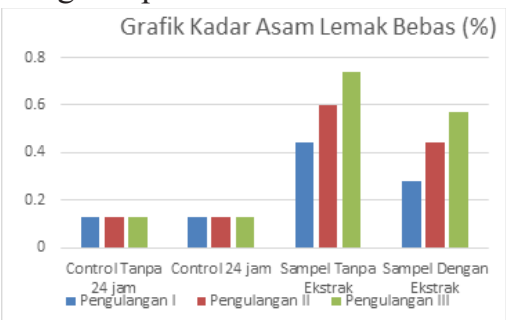

Gambar 1. Grafik Rerata Kadar Asam Lemak bebas Tabel 2. Prosentase Penurunan Kadar Asam Lemak Bebas

\begin{tabular}{|c|c|c|c|c|c|}
\hline No. & Bahan & $\begin{array}{c}\text { Rerata Kadar } \\
\text { Asam Lemak } \\
\text { Bebas Tanpa } \\
\text { Ekstrak (\%) }\end{array}$ & $\begin{array}{c}\text { Rerata Kadar } \\
\text { Asam Lemak } \\
\text { Bebas Dengan } \\
\text { Ekstrak (\%) }\end{array}$ & $\begin{array}{c}\text { Penurunan } \\
\text { Asam } \\
\text { Lemak } \\
\text { Bebas (\%) }\end{array}$ & $\begin{array}{c}\text { Prosentase } \\
\text { Penurunan } \\
\text { Asam Lemak } \\
\text { Bebas (\%) }\end{array}$ \\
\hline 1. & P1 & 0,44 & 0,28 & 0,16 & 36,36 \\
\hline 2. & P2 & 0,60 & 0,44 & 0,16 & 26,67 \\
\hline 3. & P3 & 0,74 & 0,57 & 0,17 & 22,97 \\
\hline
\end{tabular}

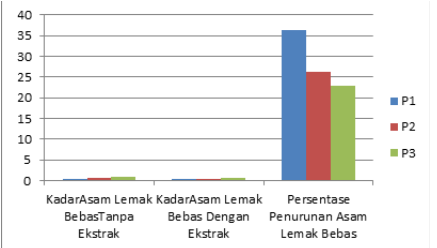

Gambar 2. Grafik Prosentase Penurunan Kadar Asam Lemak bebas 
Tabel 3. Test of Homogeneity of Variances

Kadar Asam Lemak Bebas

\begin{tabular}{|c|c|c|c|}
\hline $\begin{array}{c}\text { Levene } \\
\text { Statistic }\end{array}$ & df1 & df2 & Sig. \\
\hline 3,156 & 3 & 8 &, 086 \\
\hline
\end{tabular}

\section{e. Data Uji Statistik}

Hasil analisis data dengan menggunakan Anova satu jalan, terlihat ada beda nyata antara perlakuan dengan kadar asam lemak bebas. Sebelum menguji hipotesis dengan Anova, uji normalitas dan homogenitas dilakukan terhadap data kadar asam lemak bebas. Data dapat dikatakan tersebar secara normal dan homogen jika nilai signifikansinya lebih dari $0,05(\mathrm{p}>0,05)$. nilai homogenitas sebesar 0,086 ( $>00,05)$. Hasil tersebut menunjukkan bahwa data tersebar secara normal dan homogen.

Selanjutnya, uji Anova satu jalan dapat dilakukan dengan syarat nilai Sig 0,00 yang lebih kecil daripada nilai Asymp.sig $=0,05$. Pada analisis tersebut didapatkan beda nyata antara perlakuan penambahan ekstrak bawang merah dengan penggorengan berulang $(\mathrm{p}=0.00 ; \mathrm{p}<0,05)$, maka perlu dilakukan uji lanjutan (Post Hoc Test) untuk mengetahui secara spesifik penggunaan ekstrak bawang merah dengan penggorengan berulang yang menghasilkan kadar asam lemak bebas paling tinggi dan paling rendah. Uji lanjutan dilakukan dengan menggunakan metode uji Student Newman-Keuls (Yulius, 2010).

Pada Tabel 1 disajikan data penetapan kadar asam lemak bebas pada kontrol tanpa disimpan 24 jam, kontrol yang disimpan 24 jam, dengan perlakuan sampel tanpa diberi ekstrak bawang merah, dengan perlakuan sampel dengan penambahan ekstrak bawang merah. Pada penentuan kadar asam lemak bebas kontrol tanpa disimpan 24 jam tersebut diperoleh kadar 0,13\%. Pada penentuan kadar asam lemak bebas dengan perlakuan kontrol 24 jam juga diperoleh kadar $0,13 \%$. Pada penetapan kadar asam lemak bebas dengan perlakuan sampel tanpa diberi ekstrak bawang merah diperoleh kadar (P1) 0,44\%, (P2) 0,60\%, (P3) 0,74\%. Pada penetapan kadar asam lemak bebas dengan perlakuan sampel diberi ekstrak bawang merah dan disimpan 24 jam diperoleh kadar (P1) 0,28\%, (P2) 0,44\%, (P3) 0,57\%. Pada sampel kontrol tidak ada perbedaan dari perlakuan yang diberikan yaitu tanpa dan dengan penyimpanan 24 jam. Menurut SNI 2006 kadar tersebut masuk dalam angka aman untuk digunakan karena batas maksimum kadar asam lemak bebas minyak goreng secara umum yang diperbolehkan adalah $0,50 \%$.

Pada penetapan kadar asam lemak bebas dengan perlakuan sampel tanpa diberi ekstrak bawang merah, terdapat kenaikan kadar asam lemak bebas setelah dilakukan penggorengan pertama, kedua, dan ketiga. Menurut SNI (2006) kadar asam lemak setelah dilakukan penggorengan pertama masih dalam batas aman yaitu $0,50 \%$. Namun setelah dilakukan penggorengan kedua dan ketiga kualitas mutu minyak goreng kelapa sawit sudah melebihi ambang batas yang diperbolehkan yaitu $0,50 \%$.

Pada penetapan kadar asam lemak bebas dengan perlakuan sampel dengan penambahan ekstrak bawang merah, kadar asam lemak bebas setelah dilakukan penggorengan pertama, kedua, masih memenuhi ambang batas yang ditetapkan yaitu $0,50 \%$. Kemudian, setelah dilakukan penggorengan ketiga kadar tersebut melebihi ambang batas yang diperbolehkan dalam kelompok minyak goreng kelapa sawit (Anonim, 2006).

PadaTabel 2 disajikan data prosentase penurunan kadar rata-rata asam lemak bebas dengan semua perlakuan. Perlakuan sampel tanpa penambahan ekstrak bawang merah dengan penambahan ekstrak bawang merah pada (P1), (P2), (P3) secara berurutan terdapat penurunan $36,36 \%$, 
26,67\%, 22,97.

Pada grafik kenaikan kadar asam lemak bebas terdapat perbedaan peningkatan kadar asam lemak bebas. Pada perlakuan tanpa penambahan bawang merah terjadi peningkatan kadar asam lemak bebas yang lebih cepat yaitu $0,44 \%, 0,60 \%$, $0,74 \%$. Pada perlakuan dengan pemberian ekstrak bawang merah mengalami peningkatan kadar asam lemak bebas lebih lambat yaitu $0,28 \%$, $0,44 \%, 0,57 \%$.

Penambahan ekstrak bawang merah dapat menghambat peningkatan nilai kadar asam lemak bebas pada minyak yang telah digunakan berulang. Hal ini dikarenakan dalam ekstrak bawang merang terdapat kandungan senyawa antioksidan flavonol yang dapat menghambat peningkatan kadar asam lemak bebas. Semakin tinggi kadar asam lemak bebas menandakan kualitas minyak yang sudah menurun. (Panagan, 2010). Uji statistik menunjukkan adanya pengaruh nyata pemberian ekstrak bawang merah terhadap penurunan kadar asam lemak bebas pada penggunaan penggorengan berulang pada minyak kelapa sawit.

\section{KESIMPULAN DAN SARAN Kesimpulan}

1. Minyak goreng kelapa sawit yang digunakan untuk menggoreng tempe secara berulang pada kontrol tanpa penyimpanan 24 jam dan dengan penyimpanan 24 jam tanpa dilakukan proses penggorengan diperoleh kadar asam lemak bebas $0,13 \%$

2. Rerata Kadar Asam Lemak Bebas perlakuan sampel (P1), (P2), (P3) tanpa ekstrak berturutturut adalah $0,44 \%, 0,60 \%, 0,74 \%$. Pada penentuan sampel (P1), (P2), (P3) dengan ekstrak ba- wang merah berturut-turut adalah $0,28 \%, 0,44 \%$, $0,57 \%$.

3. Uji statistik menunjukkan adanya pengaruh nyata pemberian ekstrak bawang merah terhadap penurunan kadar asam lemak bebas pada penggunaan penggorengan berulang pada minyak kelapa sawit.

\section{Saran}

Penggunaan minyak yang berkualitas rendah tidak baik untuk kesehatan, masyarakat diharapkan dapat menggunakan minyak goreng dengan sesuai syarat yang telah ditetapkan Standar Nasional Indonesia dengan tidak menggunakan minyak yang telah digunakan berulang-ulang.

\section{DAFTAR PUSTAKA}

Anonim. 2006. Minyak Kelapa Sawit Mentah (Crude Palm Oil). Jakarta : Badan Standardisasi Indonesia.

Ayucitra, Ayuning. 2011. "Potensi Senyawa Fenolik Bahan Alami Sebagai Antioksidan Alami Minyak Goreng Nabati”. Jurnal Widya Teknik, volume 10(1): 1-11.

Ayustaningwarno, Fitriyono. 2012. "Proses Pengolahan dan Aplikasi Minyak Sawit Merah Pada Industri Pangan”. Jurnal Vitasphere,(2) : 1-11.

Brewer, M.S. 2011. "Natural Antioxidant : Sources, Compounds, Mechanism of Action, and Potential Applications". Journal of Institute of Food and Technology, volume 10 : 221-241.

Gunawan, et al. 2003. "Analisis Pangan : Penentuan Angka Peroksida dan Asam Lemak Bebas Pada Minyak Kedelai Dengan Variasi Menggoreng”. Jurnal JSKA volume 6(3): 1-6.

Karneli, et al. 2015."Pengaruh Ekstrak Bawang Merah (Allium ascalonicum L.) Terhadap Pertumbuhan Staphylococcus aureus" (Online) http://jurnal.poltekkespalembang.ac.id/ wp-content/uploads/2015/04/11-jurna-karneli-witi-okt2014.pdf. Diakses 29 November 2015

Ketaren, S. 2012. Pengantar Teknologi Minyak dan Lemak Pangan. Jakarta: Universitas Indonesia Press

Panagan, Almunady. 2010. "Pengaruh Penambahan Bubuk Bawang Merah Alliumascalonicum) Terhadap Bilangan Peroksida dan Kadar Asam Lemak Bebas Minyak Goreng Curah". Jurnal Penelitian Sains, edisi khusus(10): 17-19.

Senja, et al. 2014. "Perbandingan Metode Ekstraksi Dan Variasi Pelarut Terhadap Kadar Dan Aktivitas Antioksidan Ektrak Kubis Ungu (Brassica oleracea L. var. capitata f. rubra). Jurnal Trad. Med, volume 19(1): 43-48.

Yulius, Oscar. 2010. SPSS 18 Smarter dan Faster Mengerjakan Statistika. Yogyakarta: Panser Pustaka 